\title{
The model high molecular weight DOC compound, dextran, is ingested by the benthic ciliate Uronema marinum but does not supplement ciliate growth
}

\author{
Matthew R. First ${ }^{1,2, *}$, James T. Hollibaugh ${ }^{1}$ \\ ${ }^{1}$ University of Georgia, Department of Marine Sciences, Marine Science Building, Athens, Georgia 30602-3636, USA \\ ${ }^{2}$ Present address: Woods Hole Oceanographic Institute, Woods Hole, Massachusetts 02543, USA
}

\begin{abstract}
Phagotrophic ciliates are capable of growth solely on dissolved compounds in laboratory cultures. Whether ciliates use dissolved compounds in the environment for growth is unclear. We investigated the ability of the marine benthic ciliate Uronema marinum to ingest a model high molecular weight dissolved organic carbon (HMW-DOC) compound, dextran, at concentrations typical for coastal salt marsh sediments ( $3 \mu \mathrm{M}$ to $3 \mathrm{mM}$ C). Ingestion was measured by incubating ciliates with fluorescein-labeled dextran $(2000 \mathrm{kDa})$ and measuring the fluorescence signal of the labeled compound in cells via flow cytometry. Ciliates accumulated dextran (relative to formalin-killed controls) at concentrations as low as $0.1 \mathrm{mg} \mathrm{l}^{-1}$ dextran $(3 \mu \mathrm{M} \mathrm{C})$. Labeled dextran accumulated in food vacuoles and near the buccal cavity; thus, the ingestion of dextran appears to be a consequence of feeding activities rather than transport across the cell membrane via parasomal sac formation. Dextran accumulation did not increase with higher bacterial ingestion rates. Instead, dextran accumulation was greatest at intermediate bacterial concentrations and grazing rates. Ciliate growth rates were measured in treatments amended with model carbon compounds-soluble starch, acetate, and glucose (3 $\mathrm{mM} \mathrm{C}$, final concentrations). There was no significant increase in ciliate growth rates with these compounds in either bacteria-free or bacteria-enriched treatments. Rather, growth rates were significantly lower in treatments with DOC addition, indicating that processing of these DOC compounds may incur some energetic cost to these ciliates.
\end{abstract}

KEY WORDS: Ciliate - Microbenthos - Cell metabolism - Benthic food web - Carbohydrates . Pinocytosis

\section{INTRODUCTION}

Phagotrophic protists rely upon the ingestion of organic particulates (e.g. bacteria, algae) to satisfy their cellular metabolic requirements. However, some protists are capable of growth in axenic media through ingestion of dissolved materials (Soldo \& Van Wagtendonk 1969, Hanna \& Lilly 1974, Orias et al. 2000). Dissolved compounds can enhance growth of natural populations of bacterivorous protists, even among bacteria competing for these compounds. For example, planktonic estuarine flagellates exhibited increased growth when incubated with high molecular weight dissolved organic carbon (HMW-DOC) in the form of dextran, a linear carbohydrate composed of dextrose subunits with molecular weight approximately $2000 \mathrm{kDa}$ (Sherr 1988). This result, along with another study (Tranvik et al. 1993), indicates that HMW-DOC supplements the energy obtained by flagellates via bacterivory, resulting in increased flagellate growth.

Although ciliates are capable of growth solely on dissolved compounds in cultures (Hanna \& Lilly 1970, Thiele et al. 1980), the importance of DOC to metabolic requirements of natural populations of ciliates is not clear. Ciliates in carbon-rich environments, such as the rumen of cattle, use soluble carbohydrates but must also ingest bacteria for growth (Gutiérrez \& Hungate 1957). Pelagic choreotrichous ciliates do not appear to 
directly assimilate fluorescently-labeled macromolecules (Tranvik et al. 1993). Protists adapted to high concentrations of humic substances appear more likely to ingest HMW-DOC (Legrand \& Carlsson 1998). Thus ciliates adapted to high concentrations of HMW-DOC, as found in coastal sediments, may more readily ingest dissolved compounds to supplement energy obtained through bacterivory.

In shallow water marine sediments, HMW-DOC is released from the breakdown of plant matter and the production of exopolymeric substances by benthic microalgae (e.g. Wheeler 1976, Smith \& Underwood 1998). Bacteria must hydrolyze large macromolecules extracellularly and, in some cases, the absence of specific hydrolytic enzymes can hinder organic matter decomposition (Arnosti 2004). The breakdown of HMW-DOC in ciliate food vacuoles, whether deliberate or fortuitous, would not require additional hydrolytic enzymes (and energy expenditures), allowing ciliates to effectively compete with bacteria for HMW-DOC. Indeed, DOC has been suggested as an energy source for benthic ciliates when the rate of particle ingestion appears lower than required for cell metabolism and growth (Epstein 1997). Ciliates are one of the most abundant groups of benthic bacterivorous protists (Fenchel 1967, Dietrich \& Arndt 2000) and their role in processing sediment DOC could be significant.

Uronema marinum is a ubiquitous bacterivorous ciliate found in salt marsh surface sediments (First \& Hollibaugh 2008). We used U. marinum as a model ciliate to test the hypotheses that (1) bacterivorous ciliates are capable of direct ingestion of HMW-DOC at concentrations typical of salt marsh sediments, (2) the rate of HMW-DOC accumulation is dependent upon the rate of bacterial grazing (i.e. the amount of particulate material ingested), and (3) DOC ingestion can increase the growth rate of $U$. marinum. The primary route in which DOC enters the food web is through bacterial production; bacterial production supports the growth of bacterivorous protists (Azam et al. 1983). Understanding alternative routes of carbon flow will provide insight into food web efficiency and microbial trophodynamics in marine sediments.

\section{MATERIALS AND METHODS}

Culture establishment. Uronema marinum was isolated from sandy subtidal sediments on Sapelo Island, Georgia, USA $\left(31.389^{\circ} \mathrm{N}, 81.264^{\circ} \mathrm{W}\right)$, in November 2005. Proteose peptone ( $\mathrm{PP}, 1 \mathrm{~g} \mathrm{l}^{-1}$ ) was added to the sediment to stimulate bacterial growth, which led to a bloom of scuticociliates. A small volume $(0.5 \mathrm{ml})$ of the ciliate cultures with the natural bacterial assemblage was transferred into $30 \mathrm{ml}$ of particle-free $(0.22 \mu \mathrm{m}$ filtered) $30 \mathrm{ppt}$ artificial seawater (ASW; McLachlan 1964) enriched with $1 \mathrm{~g} \mathrm{l}^{-1}$ of PP. Fresh cultures were started every 1 to $3 \mathrm{~d}$ using this procedure. The concentration of ciliates in culture was monitored by counting formalin-preserved cells using a hemocytometer. Ciliate concentrations stabilized after 1 to $2 \mathrm{~d}$ at approximately $10^{5}$ cells $\mathrm{ml}^{-1}$, at which point the population was considered to be in stationary growth. Ciliate cultures were incubated at $22 \pm 1^{\circ} \mathrm{C}$ in tissue culture flasks.

Microscopic analysis was performed to verify that the cultures were composed of a single protist. Live cultures were observed using light microscopy (differential interference contrast, 1000×). Cultures were also observed using epifluorescence microscopy. Briefly, the culture was preserved with formalin (2\% final concentration), stained with the DNA label DAPI, and collected on a $0.22 \mu \mathrm{m}$ black polycarbonate filter. These filters were viewed on a Lecia DMX RA microscope at $1000 \times$ using the standard light filter set for DAPI fluorescence. Only one ciliate morphotype was identified in the cultures.

The ciliate was identified based on cell morphology. Ciliate morphology was observed by Protargol staining, which was performed following standard protocols (Skibbe 1994). Protargol staining allows for the visualization of key morphological features, such as the distribution patterns of cilia on the cell surface and the structure of the oral apparatus. These characteristics were used to identify the ciliate in culture using a taxonomic guide (Carey 1992).

Ciliates used in experiments were incubated for at least $1 \mathrm{~d}$ after inoculating new cultures, when the population was at or near stationary growth. The culture media was screened through a $37 \mu \mathrm{m}$ Nitex mesh to remove aggregates. Ciliates were washed by concentrating the media on a $5 \mu \mathrm{m}$ Nuclepore polycarbonate filter and rinsing with several volumes of ASW. The filter was always covered with $>1 \mathrm{~cm}$ of water during the rinsing process to avoid drying the filter. The washing process removed carbon-rich media and reduced the standing stock of bacteria to an average concentration of $8.1 \pm 0.5(\mathrm{SE}) \times 10^{5}$ cells $\mathrm{ml}^{-1}$ (determined by flow cytometry, described in 'Grazing and dextran ingestion'). This bacterial concentration is below the grazing threshold for Uronema sp. $\left(10^{6}\right.$ cells ml $^{-1}$; Kujawinski et al. 2000). This washing procedure was performed prior to all experimental manipulations. Ciliates were held for $2 \mathrm{~h}$ prior to experimental manipulations to allow for digestion of intracellular bacteria.

Antibiotics (0.1 $\mathrm{mg} \mathrm{ml}^{-1}$ gentamicin sulfate) were added to prevent further bacterial growth. This antibiotic treatment was effective at preventing the growth of bacteria in the enriched media described above. 
Gentamicin was used because it does not penetrate eukaryotic cells (Vaudaux \& Waldvogel 1979). We tested whether this antibiotic treatment affects ciliate growth (see 'Effect of antibiotics on ciliates').

Heat-killed bacteria were prepared for DOC ingestion and grazing experiments to assure that bacterial prey were uniform across treatments. Bacteria were isolated from Uronema marinum cultures on ASW agar plates (10 $\mathrm{g} \mathrm{l}^{-1}$ peptone). One colony was suspended in $1 \mathrm{ml}$ seawater and killed by heating to $95^{\circ} \mathrm{C}$ for $10 \mathrm{~min}$. Bacteria were centrifuged $(10 \mathrm{~min}$ at $10000 \times \mathrm{g})$ and the supernatant was discarded. Cells were then resuspended in ASW containing antibiotics. This washing procedure was repeated a total of 3 times. Suspended heat-killed cells were then filtered through a $5 \mu \mathrm{m}$ pore size syringe filter to disperse or remove large aggregates. Microscope observations assured that the cells were well dispersed and intact. Treated bacteria did not grow on agar plates, indicating that this treatment was sufficient to kill bacteria.

Dextran ingestion. Fluorescein isothiocyanate (FITC)labeled dextran (average molecular weight $2000 \mathrm{kDa}$, Sigma-Aldrich) was used as an analog for HMW-DOC. The FITC-dextran was prepared in 10X stock solutions and each concentration was syringe-filtered $(0.22 \mu \mathrm{m})$ immediately before use. The FITC-dextran was added to triplicate Uronema marinum cultures at final concentrations ranging from 0.1 to $100 \mathrm{mg} \mathrm{l}^{-1}(3 \mu \mathrm{M}$ to $3 \mathrm{mM} \mathrm{C}$ ). ASW was added to one triplicate set as a negative control. One formalin-killed control ( $2 \%$ final concentration) was run at each concentration to account for the background fluorescence of the media and passive adsorption of dextran on ciliate cell bodies. The samples $(1 \mathrm{ml})$ were incubated for $90 \mathrm{~min}$ in the dark at $22^{\circ} \mathrm{C}$ on a shaker table ( 50 rpm). Incubations were stopped by formalin addition ( $2 \%$ final concentration).

Accumulation of FITC-dextran leads to an increase of the fluorescence signal in the ciliate relative to the background fluorescence. The fluorescence of individual ciliates was measured using a flow cytometer (Dako CyAn) with a $488 \mathrm{~nm}$ laser excitation. Ciliates were identified by their forward and side angle light scattering signals. The FITC fluorescence emission signals (FL1, 530/30 nm emission filter) for approximately 5000 ciliates were recorded for each treatment replicate and control. Epifluorescence and laser scanning confocal microscopy were used to verify the accumulation of FITC-dextran in ciliate food vacuoles. Cells were imaged at $1000 \times$ with a combination of fluorescence emission in the green light spectrum and transmitted light from a $488 \mathrm{~nm}$ argon/krypton laser.

The relative rate of HMW-DOC accumulation in Uronema marinum was measured by incubating ciliates at 3 concentrations of FITC-dextran. Triplicate cil- iate cultures were prepared in $50 \mathrm{ml}$ conical centrifuge tubes as described above and incubated with 1, 10, and $100 \mathrm{mg} \mathrm{l}^{-1}$ FITC-dextran for a total of $300 \mathrm{~min}$. Samples $(1 \mathrm{ml})$ were collected from each replicate periodically throughout the incubation period (at 0, 15, 30, 60, 90, $120,180,240$, and $300 \mathrm{~min}$ ) to determine the rate of FITC-dextran accumulation. Formalin-killed controls were also run to measure the background fluorescence of the solution. The fluorescent emission signal was recorded for approximately 5000 ciliates as described above, subtracting the mean fluorescence of the killed control. To measure the relative accumulation of dextran over time, the final ciliate fluorescence was normalized to the initial concentration. The relative accumulation (RA) of FITC-dextran was calculated as the mean fluorescence at each time point $\left(T_{i}\right)$ normalized to the mean fluorescence at the initial time point $\left(T_{0}\right)$ according to the formula:

$$
\mathrm{RA}_{T_{i}}=\mathrm{FL}_{T_{i}} / \mathrm{FL} 1_{T_{0}}
$$

Thus an RA of 1 indicates that there was no change in fluorescence over the incubation period (i.e. no ingestion of dextran). We used this relative measurement because there were large differences in background fluorescence due to the extracellular dextran in the solutions. For example, absolute fluorescence of $T_{0}$ treatments of $100 \mathrm{mg} \mathrm{l}^{-1}$ dextran was greater than final $\left(T_{300}\right)$ fluorescence in $10 \mathrm{mg} \mathrm{l}^{-1}$ solutions (See Fig. 1).

Grazing and dextran ingestion. We also tested the hypothesis that DOC accumulation increases concurrently with higher bacterial grazing rates. In theory, higher grazing rates can lead to increased food vacuole formation (Parker 1976). Alternatively, DOC ingestion may become more important when bacterial concentrations are low. Ciliate cultures were prepared as above and the washed culture was transferred into $50 \mathrm{ml}$ conical centrifuge tubes. Two variables (bacteria and dextran concentration) were analyzed at 3 levels: low, medium, and high bacteria concentrations and 0 , 10, and $100 \mathrm{mg} \mathrm{l}^{-1}$ dextran. Heat-killed bacteria were prepared as described above and added to the cultures to yield approximately $8.1,15$, and $110 \times 10^{5}$ cells ml $^{-1}$ for low, medium, and high treatments, respectively (concentrations were determined by flow cytometry). The volume of sample analyzed was determined by weighing the sample before and after analysis (Rose et al. 2004). Treatments were immediately dispensed into $2 \mathrm{ml}$ Eppendorf tubes. The samples were incubated for 90 min as described above. Ciliate and bacteria concentrations and ciliate fluorescence were measured at both initial and final time points by flow cytometry. Additional samples were incubated for $26 \mathrm{~h}$ to assess long-term ciliate growth in these treatments as described in 'Starch, glucose, and acetate amendments'. Per capita grazing rates were calculated as 
the loss of bacterial cells during the 90 min incubation per the mean ciliate concentration $\left(C_{\mathrm{M}}\right)$ :

$$
C_{\mathrm{M}}=C_{T_{0}} e^{(\mu \Delta t / 2)}
$$

where $C_{T_{0}}$ is the initial ciliate concentration (cells ml-1) (Gallegos et al. 1996), $\mu$ is ciliate growth rate, and $t$ is incubation time. Ciliate growth rate was determined by the equation:

$$
\mu=\ln \left(C_{T_{\mathrm{f}}} / C_{T_{i}}\right) / t
$$

where $C_{T_{\mathrm{f}}}$ is the final ciliate concentration at the end of the incubation time $(t)$. Ciliate growth rate $\left(\mathrm{d}^{-1}\right)$ was calculated for samples incubated for $26 \mathrm{~h}$.

Starch, glucose, and acetate amendments. The role of dissolved carbon compounds commonly found in salt marsh sediments was examined by measuring the growth rates of Uronema marinum incubated with starch, glucose, and acetate in both the presence and absence of bacteria. Glucose constitutes over $80 \%$ of colloidal monosaccharides in diatom-dominated, intertidal sediments (Taylor et al. 1999). Acetate is an abundant, low molecular weight DOC in intertidal sediments, especially in anoxic zones (Holmer 1996). Soluble starch was used as a representative HMW-DOC compound. Soluble starch, sodium acetate, and D-glucose were dissolved in filter-sterilized ASW; the starch solution was heated $\left(\sim 60^{\circ} \mathrm{C}\right)$ to speed dissolution. All solutions were prepared in cleaned and baked $\left(550^{\circ} \mathrm{C}, 6 \mathrm{~h}\right)$ glassware. Solutions were syringe-filtered through a $0.22 \mu \mathrm{m}$ membrane filter prior to use in the experiment and diluted to yield a final concentration of $3 \mathrm{mM} \mathrm{C}$ in all treatments, which is in the range observed in salt marsh surface sediments (Weston et al. 2006).

Flow cytometric sorting was used to completely separate Uronema marinum from bacteria in cultures. The ciliates were identified based on forward and side angle light scattering signals on a Dako MoFlo high speed cell sorter. Ciliates were sorted into particle-free ASW and held for $2 \mathrm{~h}$ prior to the experiment. The process of cell sorting had no observable effect on the growth rate or activity of $U$. marinum, as verified by microscope analysis of live samples and incubating sorted ciliates with heat-killed bacteria. Sorted ciliates were motile and would reproduce when bacteria were added to the cultures.

Treatments were prepared in autoclaved, $2 \mathrm{ml} \mathrm{Ep-}$ pendorf tubes. Triplicates of each treatment were prepared by adding $100 \mu \mathrm{l}$ of sorted Uronema marinum to $800 \mu \mathrm{l}$ of starch, acetate, or glucose solutions. Filtersterilized ASW was used for control treatments. For treatments with bacteria, $100 \mu \mathrm{l}$ of the heat-killed bacterial suspension was added. Bacteria-free treatments received $100 \mu \mathrm{l}$ of filter-sterilized ASW with antibiotics. The final antibiotic concentration for all treatments was $0.1 \mathrm{mg} \mathrm{ml}^{-1}$ of gentamicin sulfate. Initial $\left(T_{0}\right)$ samples were chemically preserved with $0.22 \mu \mathrm{m}$ filtered formalin ( $2 \%$ final concentration). Samples were incubated in the dark at $22^{\circ} \mathrm{C}$ for $26 \mathrm{~h}$, at which point the incubation was stopped by adding formalin. Treatments were stained with DAPI $\left(20 \mu \mathrm{g} \mathrm{ml}^{-1}\right.$, final concentration) and the concentrations of ciliates and bacteria in each treatment replicate were measured with a Dako CyAn flow cytometer using a $405 \mathrm{~nm}$ laser for DAPI excitation (FL6, 450/50 nm emission filter).

In addition to estimating ciliate growth by the change in cell concentration, ciliate growth was also calculated by the change in total biomass. With this approach, the biomass concentration $\left(\mu \mathrm{g} \mathrm{C} \mathrm{ml}{ }^{-1}\right)$ rather than cell concentration is used in Eq. (3). Measuring ciliate biomass is potentially useful in calculating total ciliate carbon concentration, as the cell volume of Uronema marinum varies with ciliate growth stage (Parker 1976). Ciliates were preserved with formalin ( $2 \%$ final concentration), incubated with FITC for 10 min to stain the entire cell body, and filtered onto a $0.22 \mu \mathrm{m}$ black polycarbonate filter. Cells were visualized via epifluorescence microscopy using standard filter sets for FITC fluorescence. The initial and final ciliate biomasses were determined by measuring microscope images of $U$. marinum captured at $400 \times$ on a Hamamatsu CCD digital camera. Image dimensions were calibrated using a stage micrometer and verified using 0.66 and $1.0 \mu \mathrm{m}$ diameter fluorescent beads. The length and width of at least 30 non-dividing ciliates in each treatment were measured with image analysis software (Image Pro Plus 4.1) and used to calculate biovolume of ciliates (Wetzel \& Likens 1991). Ciliate biovolume was converted to biomass using a published carbon:volume ratio that accounts for cell shrinkage due to formalin fixation (Putt \& Stoecker 1989). The total biomass was the product of mean individual biomass and ciliate concentration.

Effect of antibiotics on ciliates. To verify that the antibiotics used to prevent bacterial growth did not affect ciliates, we compared ciliate growth in treatments with antibiotics $\left(0.1 \mathrm{mg} \mathrm{ml}^{-1}\right.$ gentamicin sulfate) versus treatments without antibiotics added. Triplicate treatments consisting of $0.5 \mathrm{ml}$ of washed ciliates were added to $30 \mathrm{ml}$ ASW containing antibiotics. Control treatments consisted of ASW without antibiotics. Heatkilled bacteria were added to all treatments to stimulate ciliate growth. These treatments were incubated for $1 \mathrm{~d}$ as described above. Ciliate growth was determined from initial and final cell concentrations using Eq. (3).

Data analysis. ANOVA was used to determine significant differences $(\alpha=0.05)$ in ciliate fluorescence, relative dextran accumulation, and ciliate growth rate. Linear regression analysis was used to determine the strength of the relationship between dextran concen- 
tration and either ciliate fluorescence or dextran accumulation. The regression coefficient is shown for significant linear relationships. Measurements reported are the mean values for 3 replicate treatments shown with standard error.

\section{RESULTS}

\section{Dextran ingestion}

There was no significant difference between ciliate growth in cultures with antibiotics versus cultures without antibiotics, indicating that the antibiotic treatment did not affect the ciliates and was appropriate to use to limit bacterial growth in these experiments. Uronema marinum incubated with FITC-labeled dextran were significantly more fluorescent than formalinkilled controls at all concentrations tested (Fig. 1). Negative controls (without dextran addition) exhibited only minor fluorescence, indicating that formalin was

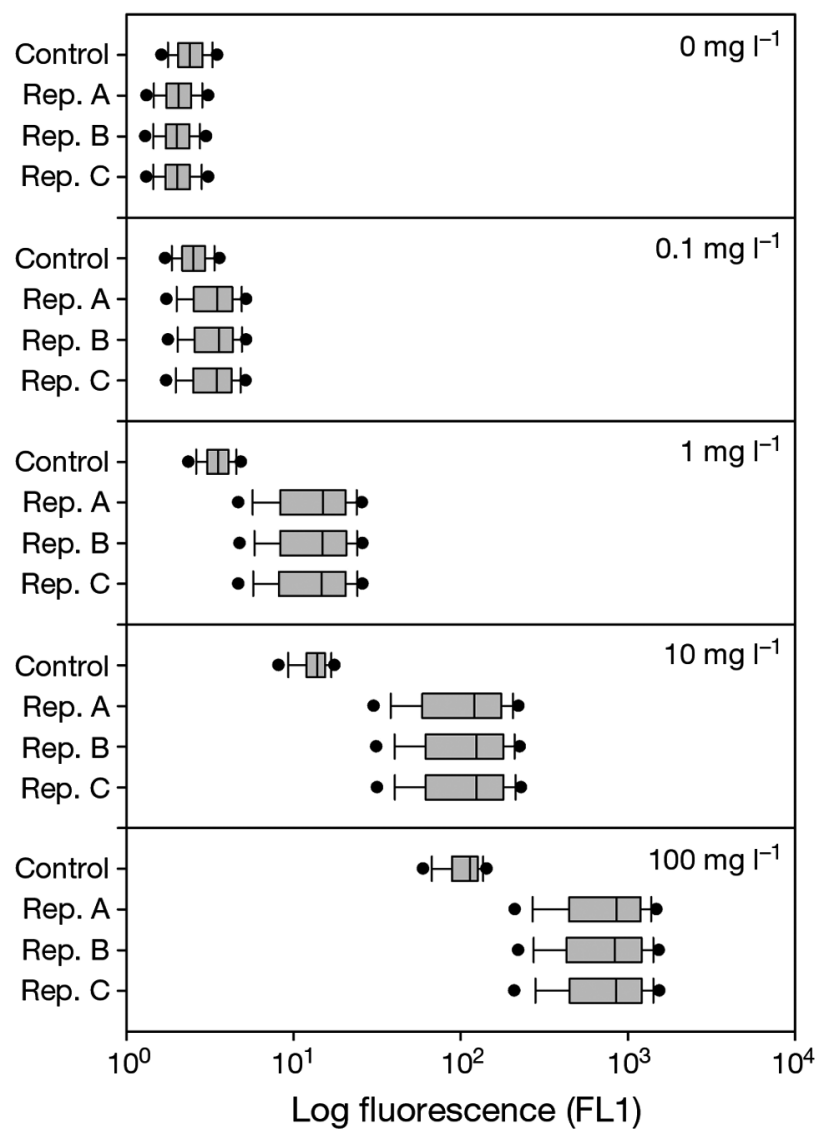

Fig. 1. Flow cytometric fluorescent signal (FL1) measured in ciliates incubated in several concentrations (0.1 to $100 \mathrm{mg} \mathrm{l}^{-1}$ ) of fluorescein isothiocyanate (FITC)-labeled dextran. The box lines show the 25th, 50th, and 75th percentiles; bars and dots indicate the 10th and 5th percentiles of the data, respectively. Three replicates (Rep.) are shown separately not a major source of the detected ciliate fluorescence. Ciliates were able to accumulate dextran in food vacuoles at concentrations as low as $0.1 \mathrm{mg} \mathrm{l}^{-1}$, and the fluorescence signal emitted by ciliates was strongly correlated to the concentration of dextran in solution $\left(\mathrm{r}^{2}=\right.$ 0.99). The fluorescence signal was concentrated in structures consistent with food vacuoles in shape, size, and location in the cell (Fig. 2). Examination by epifluorescence, confocal microscopy, and flow cytometry revealed no fluorescent particles or aggregates that could introduce the fluorescence signal into the food vacuole via phagocytosis of particles, indicating that the source of the fluorescence signal was dissolved or colloidal $(<0.22 \mu \mathrm{m})$ FITC-dextran.

The relative dextran accumulation was highly dependent on dextran concentration (Fig. 3). The slope of the relationship between relative accumulation and

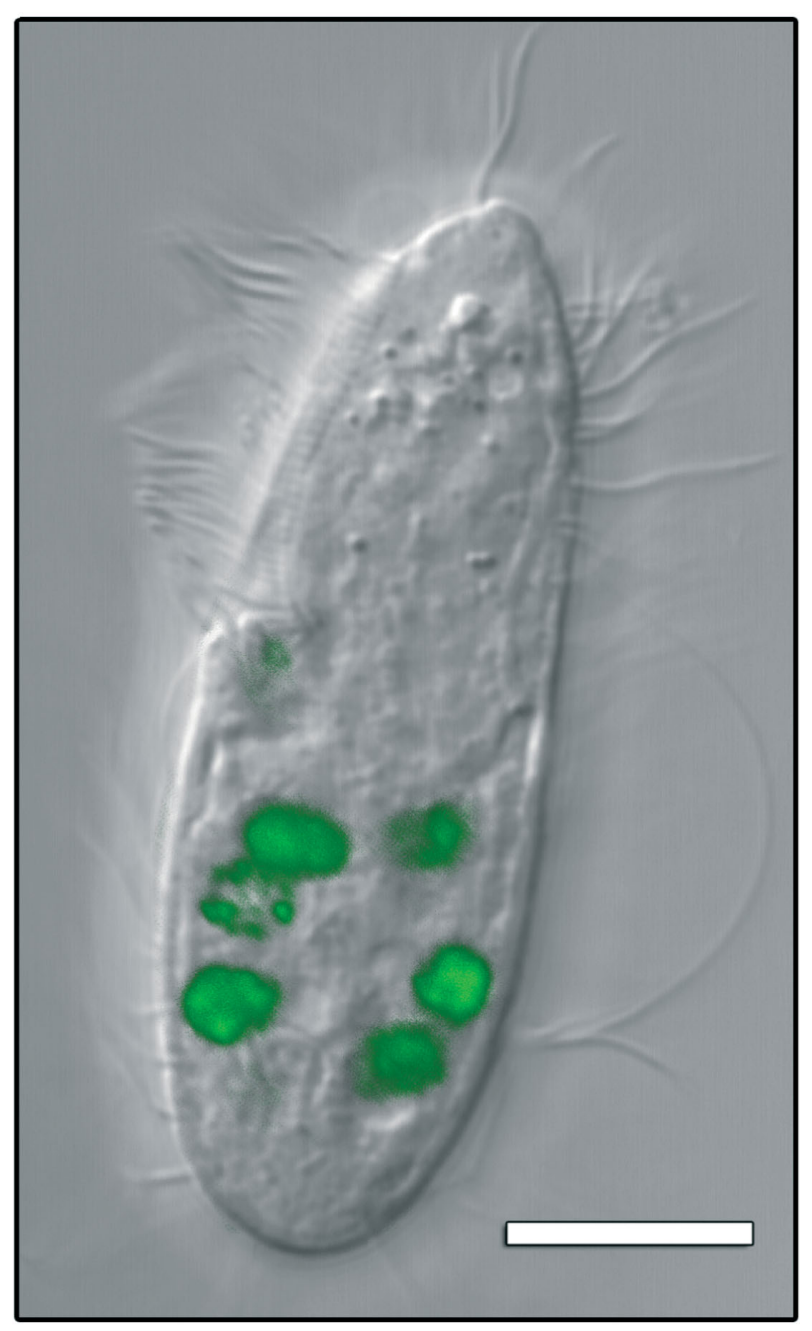

Fig. 2. Uronema marinum. Laser scanning confocal micrograph of representative $U$. marinum showing fluorescence from fluorescein isothiocyanate (FITC)-labeled dextran in food vacuoles located near the buccal cavity and the cell posterior. Scale bar $=10 \mu \mathrm{m}$ 
time was $0.003,0.009$, and $0.029 \mathrm{~min}^{-1}$ for 1,10 , and $100 \mathrm{mg} \mathrm{l}^{-1}$ FITC-dextran, respectively $\left(\mathrm{r}^{2}>0.9\right.$ in all cases). Ciliate fluorescence was significantly greater than initial background fluorescence after $60 \mathrm{~min}$ at all 3 dextran concentrations. The final percent enrichment after the $300 \mathrm{~min}$ incubation was $1.7 \pm 0.07,3.9 \pm 0.16$, and $8.7 \pm 0.51 \%$ for 1,10 , and $100 \mathrm{mg} \mathrm{l}^{-1}$ dextran, respectively. In all 3 dextran concentrations, the rate of change in mean fluorescence decreased after $180 \mathrm{~min}$ (Fig. 3).

Dextran accumulation by ciliates was highest at intermediate bacterial concentrations (Fig. 4A) and was significantly greater than accumulation at both low and high bacteria concentrations. There was no significant difference in relative accumulation of dextran between high and low bacteria treatments at either 10 or $100 \mathrm{mg} \mathrm{l}^{-1}$ dextran. Ciliate grazing rates increased with bacteria concentration, with the greatest per capita grazing rates occurring in the high bacteria concentration treatments (Fig. 4B). The growth rate of Uronema marinum measured over $1 \mathrm{~d}$ was greatest in high bacterial treatments (Fig. 5). There was no significant difference in ciliate growth rate between low and medium bacteria treatments, nor was there any significant effect of FITC-dextran on ciliate growth rate at these bacteria concentrations. The highest ciliate growth rate was measured in high bacterial concentrations without dextran addition. This growth rate was significantly greater than in the $10 \mathrm{mg} \mathrm{l}^{-1}$ FITC-dextran treatment, but not the $100 \mathrm{mg}$ $\mathrm{l}^{-1}$ treatment.

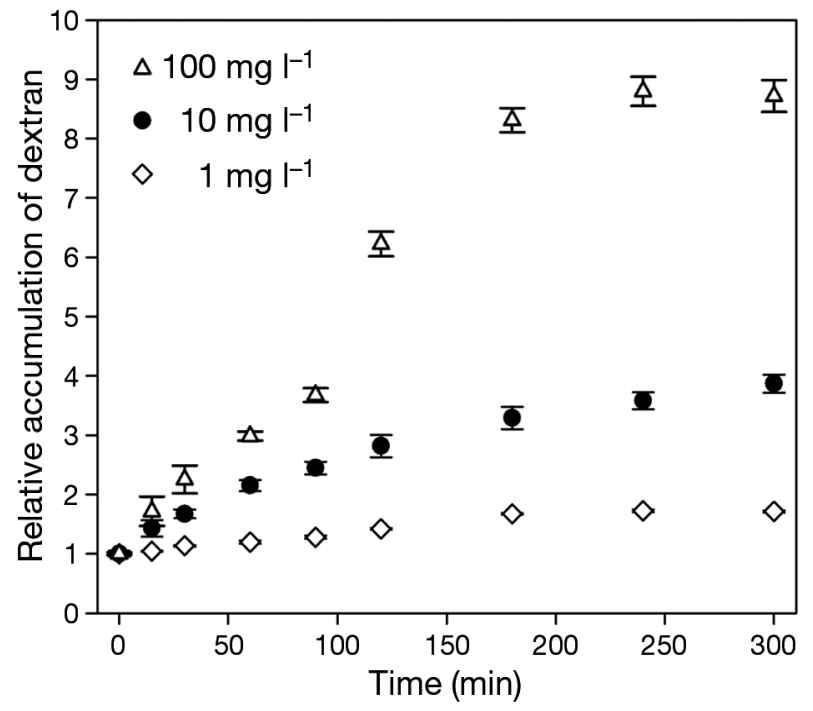

Fig. 3. Uronema marinum. Relative dextran accumulation rate in ciliates at 3 fluorescein isothiocyanate (FITC)-labeled dextran concentrations measured over a 300 min incubation period. Relative accumulation is the mean fluorescence at each time point normalized to initial mean fluorescence. Error bars are $\operatorname{SE}(n=3)$
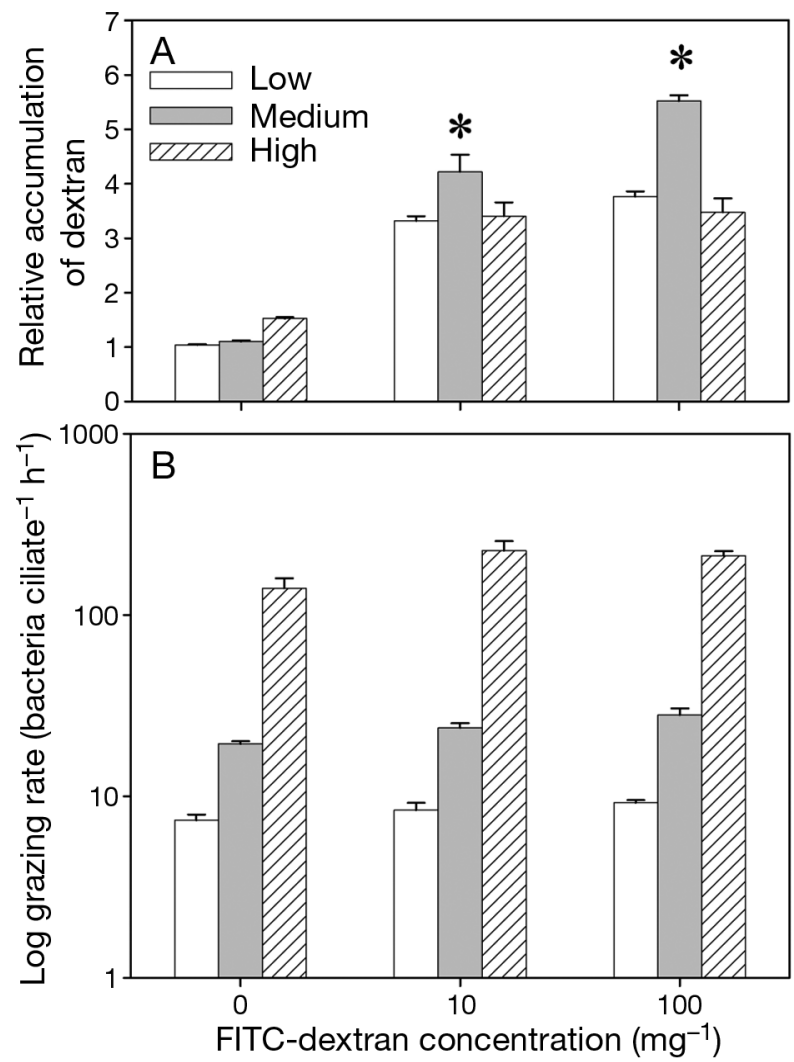

Fig. 4. Uronema marinum. (A) Relative dextran accumulation rate in ciliates treated with 0,10 , and $100 \mathrm{mg} \mathrm{l}^{-1}$ of fluorescein isothiocyanate (FITC)-labeled dextran and low, medium, and high bacterial concentrations. (B) Per capita ciliate grazing rates in all treatments. Error bars are SE $(n=3)$. Asterisks indicate a significantly higher dextran accumulation than measured in other treatments (ANOVA, $\mathrm{p}<0.05$ )

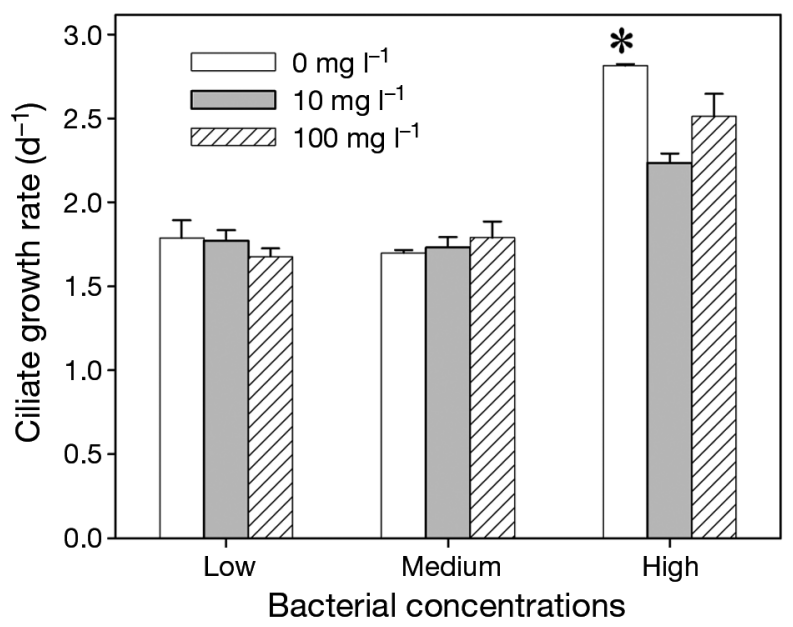

Fig. 5. Uronema marinum. Growth rate $\left(\mathrm{d}^{-1}\right)$ measured as the change in ciliate concentration over a $26 \mathrm{~h}$ incubation period. Ciliates were treated with low, medium, and high concentrations of bacteria and 0,10 , and $100 \mathrm{mg} \mathrm{l}^{-1}$ of fluorescein isothiocyanate (FITC)-labeled-dextran. Error bars are SE $(n=3)$. Asterisk indicates a significantly higher ciliate growth rate than measured in $10 \mathrm{mg} \mathrm{l}^{-1}$ dextran (ANOVA, $\mathrm{p}<0.05$ ) 
Starch, acetate, and glucose amendments

Ciliate growth rate, based on the change in concentration of cells over the incubation period, did not increase with starch, acetate, or glucose treatments relative to the controls (Fig. 6). Rather, the highest ciliate growth rates were observed in control samples without DOC addition. In bacteria treatments, ciliate growth rates in the control treatments were significantly greater than in DOC treatments. Growth rates based upon changes in biomass were higher than those based only on cell concentrations in most treatments, indicating that the mean cell biomass increased over the incubation period (Fig. 6). However, the biomass growth rates measured in DOC treatments were still not significantly greater than the control treatment.

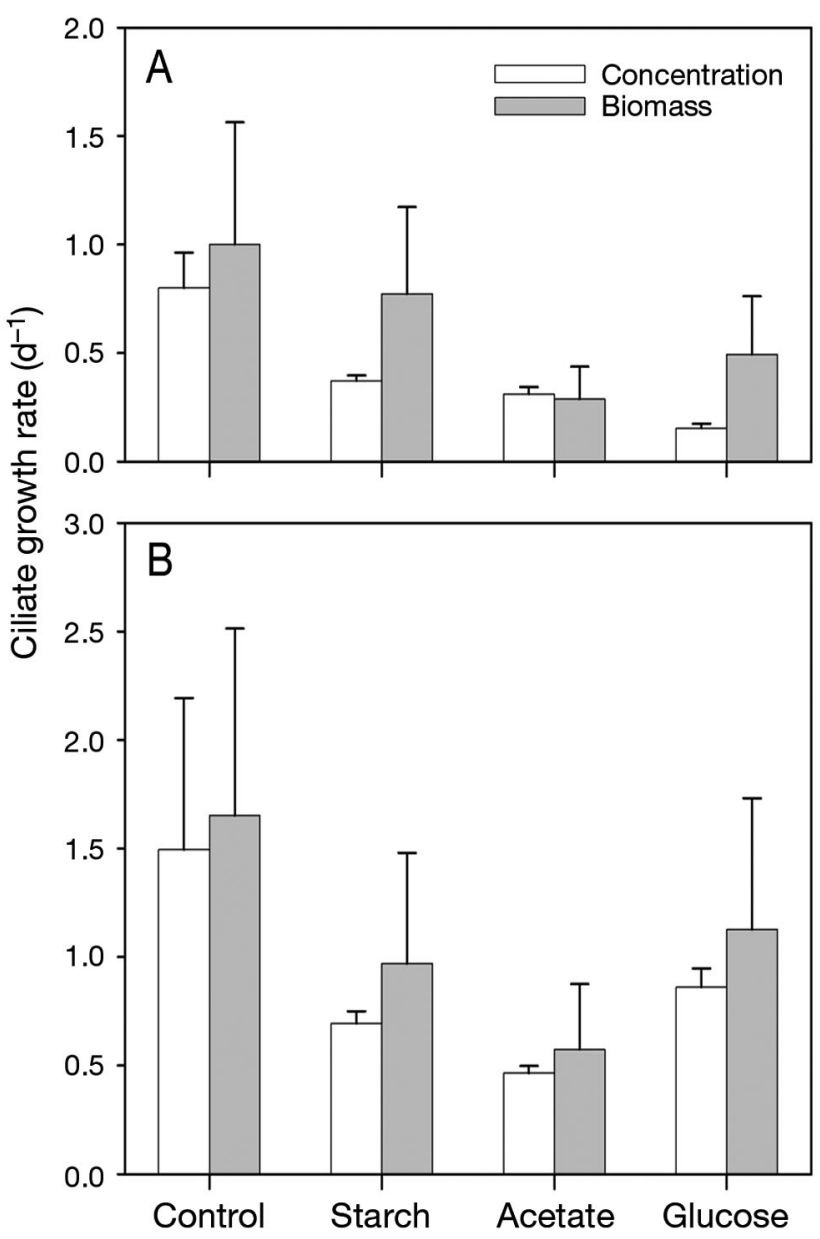

Fig. 6. Uronema marinum. Growth rate $\left(\mathrm{d}^{-1}\right)$ of ciliates determined by changes in cell concentrations (open bars) or ciliate biomass (gray bars). The ciliates were incubated in control (no dissolved organic carbon [DOC] addition), starch, acetate, and glucose treatments, with a final concentration of $3 \mathrm{mM}$ DOC. Growth rates were measured (A) without and (B) with bacteria. Error bars are SE $(\mathrm{n}=3)$

\section{DISCUSSION}

Several ciliates, including Uronema marinum, have been cultured under axenic conditions, hence their ability to ingest and metabolize DOC is well established (Soldo \& Van Wagtendonk 1969, Hanna \& Lilly 1970). We hypothesized that ciliates are capable of ingesting HMW-DOC at concentrations typical of salt marsh sediments and that DOC ingestion could supplement ciliate growth. Phagotrophic protists adapted to high concentrations of HMW-DOC may more readily ingest dissolved compounds (Legrand \& Carlsson 1998). Salt marsh sediments have high concentrations of HMW-DOC, such as lignocelluloses that originate from the breakdown of intertidal marsh grasses (Moran \& Hodson 1990). Additionally, large quantities of algal-derived exopolymers are released by benthic microalgae in shallow water sediments (Smith \& Underwood 1998). Recalcitrant carbon compounds are also produced by bacteria from labile materials, such as sugars and amino acids (Ogawa et al. 2001). Bacterial growth yield on these recalcitrant compounds is typically low (Newell et al. 1983), potentially allowing for competition by ciliates.

Uronema marinum was capable of ingesting dextran, a model HMW carbohydrate. However, DOC in solution (whether in the form of dextran, starch, glucose, or acetate) did not increase ciliate growth. Rather, the processing of these compounds appeared to incur some energetic costs to ciliates, resulting in lower growth rates at high DOC concentrations. This energetic cost may be associated with the hydrolysis of nitrogen-poor carbon compounds. Marine bacteria (the typical prey for $U$. marinum) have a high relative contribution of nitrogen to their total biomass (Fukuda et al. 1998), providing nitrogen necessary for ciliate biomass production. Although DOC consumption does not appear to significantly increase the growth rate of $U$. marinum, other benthic ciliates (including larger taxa with lower particle ingestion rates) may depend upon DOC to supplement metabolic requirements (Epstein 1997).

Dextran accumulated in ciliates within $15 \mathrm{~min}$, but the accumulation of labeled dextran changed little after $180 \mathrm{~min}$. This suggests that the rate of food vacuole formation equals the rate of vacuole egestion after about $3 \mathrm{~h}$. This vacuole passage time is much longer than determined by measuring the accumulation of bacteria in Uronema sp. food vacuoles (Sherr et al. 1988). This large difference suggests that ingesting dextran may slow the rate of ciliate food vacuole passage. While prey concentration did not affect the food vacuole passage time for other ciliates (Capriulo \& Degnan 1991), it is possible that low bacterial abundance contributed to longer vacuole passage times in dextran accumulation rate experiments. 
Because dextran accumulated in food vacuoles, we expected that greater rates of prey ingestion would lead to a higher accumulation of dextran. Uronema marinum cells contain more food vacuoles when prey are abundant (Kujawinski et al. 2000) and this should lead to greater dextran accumulation at high prey concentrations. However, high prey concentrations did not correspond to the greater uptake of dextran. One explanation for this unexpected result is that ciliate metabolism may vary depending upon prey concentration, leading to high degradation rates of dextran with few prey or rapid food vacuole passage rates when prey are abundant. However, ciliate digestion and food vacuole cycling times do not vary significantly with prey concentrations (Capriulo \& Degnan 1991). If degradation of dextran is not dependent upon prey concentration, the observation that dextran accumulation is greatest at intermediate, rather than low, prey concentrations suggests that DOC ingestion does not contribute to ciliate metabolism when prey are scarce.

The accumulation of dextran in ciliate food vacuoles indicates that HMW-DOC enters the cell via the oral cavity where prey are ingested, and that this is an active process. There was no visible evidence of active transport of dextran across the cell membrane via the formation of parasomal sacs (e.g. Radek \& Hausmann 1996). Thus, the mechanism by which dextran is concentrated and accumulated in the cell is different from other dissolved compounds. For example, Uronema sp. has been shown to accumulate chlorinated biphenyls through passive diffusion across the cell membrane (Kujawinski et al. 2000). The observation that dextran is ingested in the food vacuole suggests that cellsurface receptors with high affinity for carbohydrates near the feeding apparatus may play an important role in particle capture (Sundermann et al. 1986). It is important to note that although dextran was dissolved and filtered to remove particles $>0.22 \mu \mathrm{m}$, it is probable that a portion of this dextran existed as colloids (Verdugo et al. 2004). However, even colloids are not expected to be concentrated via suspension feeding. In suspension feeding, particles are sieved as water is passed through the paroral membrane; mechanical filtration is considered to be the major mechanism of particulate concentration (Fenchel 1980b). Some suspension feeding ciliates, such as Tetrahymena pyriformis, do not show selectivity of prey based upon cell-surface properties, such as antigen structure (Wildschutte et al. 2004). However, chemical interactions increase the ingestion rates of particulate prey by some bacterivorous flagellates and ciliates (Monger et al. 1999, Wilks \& Sleigh 2004). The ability to concentrate and ingest dissolved or colloidal matter, which would not be retained on the paroral membrane (Fenchel 1980a), suggests that molecular attraction may play a role in how Uronema marinum captures and ingests food items. HMW-DOC ingestion, although not beneficial to these ciliates, may be a consequence of cell-surface structures functioning to attract and retain bacterial prey.

Acknowledgements. This work was supported by NSF Georgia Coastal Ecosystems LTER grant (OCE-9982133). J. Shields and C. Keith assisted in the confocal microscope operation. J. Nelson provided crucial assistance in the operation of the CyAn and MoFlo flow cytometers and assisted in data analysis. J. M. Bernhard, M. A. Farmer, S. B. Joye and C. Meile provided guidance on the design of this project and comments on this manuscript. M.R.F. was also supported by a UGA Graduate School Assistantship. We appreciate the comments and suggestions of 3 anonymous reviewers, which greatly improved this manuscript. This is contribution no. 961 to UGAMI.

\section{LITERATURE CITED}

Arnosti C (2004) Speed bumps and barricades in the carbon cycle: substrate structural effects on carbon cycling. Mar Chem 92:263-273

Azam F, Fenchel T, Field JG, Gray JS, Meyer-Reil LA, Thingstad F (1983) The ecological role of water-column microbes in the sea. Mar Ecol Prog Ser 10:257-263

Capriulo GM, Degnan C (1991) Effect of food concentration on digestion and vacuole passage time in the heterotrichous marine ciliate Fibrea salina. Mar Biol 110:199-202

Carey PG (1992) Marine interstitial ciliates: an illustrated key, 2nd edn. Chapman \& Hall, Norwell, MA

$>$ Dietrich D, Arndt H (2000) Biomass partitioning of benthic microbes in a Baltic inlet: relationships between bacteria, algae, heterotrophic flagellates and ciliates. Mar Biol 136: 309-322

Epstein SS (1997) Microbial food webs in marine sediments. II. Seasonal changes in trophic interactions in a sandy tidal flat community. Microb Ecol 34:199-209

Fenchel T (1967) The ecology of marine microbenthos. I. The quantitative importance of ciliates as compared with metazoans in various types of sediments. Ophelia 4: 121-137

Fenchel T (1980a) Relation between particle size selection and clearance in suspension-feeding ciliates. Limnol Oceanogr 25:733-738

Fenchel T (1980b) Suspension feeding in ciliated protozoa: structure and function of feeding organelles. Arch Protistenkd 123:239-260

First MR, Hollibaugh JT (2008) Protistan bacterivory and benthic microbial biomass in an intertidal creek mudflat. Mar Ecol Prog Ser 361:59-68

Fukuda R, Ogawa H, Nagata T, Koike I (1998) Direct determination of carbon and nitrogen contents of natural bacterial assemblages in marine environments. Appl Environ Microbiol 64:3352-3358

Gallegos CL, Vant WN, Safi KA (1996) Microzooplankton grazing of phytoplankton in Manukau Harbour, New Zealand. N Z J Mar Freshw Res 30:423-434

Gutiérrez J, Hungate RE (1957) Interrelationship between certain bacteria and the rumen ciliate Dasytricha ruminantium. Science 126:511

Hanna BA, Lilly DM (1970) Nutrition of axenic Uronema marinum. Am Zool 10:539-570 
Hanna BA, Lilly DM (1974) Growth of Uronema marinum in chemically defined medium. Mar Biol 26:153-160

Holmer M (1996) Composition and fate of dissolved organic carbon derived from phytoplankton detritus in coastal marine sediments. Mar Ecol Prog Ser 141:217-228

Kujawinski EB, Farrington JW, Moffett JW (2000) Importance of passive diffusion in the uptake of polychlorinated biphenyls by phagotrophic protozoa. Appl Environ Microbiol 66:1987-1993

Legrand C, Carlsson P (1998) Uptake of high molecular weight dextran by the dinoflagellate Alexandrium catenella. Aquat Microb Ecol 16:81-86

McLachlan J (1964) Some considerations of growth of marine algae in artificial media. Can J Microbiol 10:769-782

Monger BC, Landry MR, Brown SL (1999) Feeding selection of heterotrophic marine nanoflagellates based on the surface hydrophobicity of their picoplankton prey. Limnol Oceanogr 44:1917-1927

Moran MA, Hodson RE (1990) Contributions of degrading Spartina alterniflora lignocellulose to the dissolved organic carbon pool of a salt marsh. Mar Ecol Prog Ser 62: 161-168

> Newell RC, Linley EAS, Lucas MI (1983) Bacterial production and carbon conversion based on saltmarsh plant debris. Estuar Coast Shelf Sci 17:405-419

Ogawa H, Amagai Y, Koike I, Kaiser K, Benner R (2001) Production of refractory dissolved organic matter by bacteria. Science 292:917-920

Orias E, Hamilton EP, Orias JD (2000) Tetrahymena as a laboratory organism: useful strain, cell culture, and cell line maintenance. In: Asai DJ, Forney JD (eds) Tetrahymena thermophila, Vol 62. Academic Press, San Diego, CA, p 189-211

Parker JG (1976) Cultural characteristics of marine ciliated protozoan, Uronema marinum Dujardin. J Exp Mar Biol Ecol 24:213-226

Putt M, Stoecker DK (1989) An experimentally determined carbon:volume ratio for marine 'oligotrichous' ciliates from estuarine and coastal waters. Limnol Oceanogr 34: 1097-1103

Radek R, Hausmann K (1996) Phagotrophy of ciliates. In: Hausmann K, Bradbury PC (eds) Ciliates: cells as organisms. Gustav Fischer, Stuttgart, p 197-219

Rose JM, Caron DA, Sieracki ME, Poulton N (2004) Counting heterotrophic nanoplanktonic protists in cultures and aquatic communities by flow cytometry. Aquat Microb Ecol 34:263-277

Sherr EB (1988) Direct use of high molecular weight polysac-

Editorial responsibility: Robert Sanders,

Philadelphia, Pennsylvania, USA charide by heterotrophic flagellates. Nature 335:348-351

Sherr BF, Sherr EB, Rassoulzadegan F (1988) Rates of digestion of bacteria by marine phagotrophic protozoa: temperature dependence. Appl Environ Microbiol 54:1091-1095

Skibbe O (1994) An improved quantitative protargol stain for ciliates and other planktonic protists. Arch Hydrobiol 130: 339-347

Smith DJ, Underwood GJC (1998) Exopolymer production by intertidal epipelic diatoms. Limnol Oceanogr 43: 1578-1591

Soldo AT, Van Wagtendonk J (1969) Nutrition of Paramecium aurelia, stock 299. J Protozool 16:500-506

Sundermann CA, Paulin JJ, Dickerson HW (1986) Recognition of prey by suctoria: the role of cilia. J Eukaryot Microbiol 33:473-475

Taylor IS, Paterson DM, Mehlert A (1999) The quantitative variability and monosaccharide composition of sediment carbohydrates associated with intertidal diatom assemblages. Biogeochemistry 45:303-327

Thiele J, Honer-Schmid O, Wahl J, Kleefeld G, Schultz J (1980) A new method for axenic mass cultivation of Paramecium tetraurelia. J Protozool 27:118-121

Tranvik LJ, Sherr EB, Sherr BF (1993) Uptake and utilization of 'colloidal DOM' by heterotrophic flagellates in seawater. Mar Ecol Prog Ser 92:301-309

Vaudaux P, Waldvogel FA (1979) Gentamicin antibacterial activity in the presence of human polymorphonuclear leukocytes. Antimicrob Agents Chemother 16:743-749

> Verdugo P, Alldredge AL, Azam F, Kirchman DL, Passow U, Santschi PH (2004) The oceanic gel phase: a bridge in the DOM-POM continuum. Mar Chem 92:67-85

> Weston NB, Porubsky WP, Samarkin VA, Erickson M, Macavoy SE, Joye SB (2006) Porewater stoichiometry of terminal metabolic products, sulfate, and dissolved organic carbon and nitrogen in estuarine intertidal creekbank sediments. Biogeochemistry 77:375-408

Wetzel RG, Likens GE (1991) Limnological analysis, 2nd edn. Springer Verlag, New York

Wheeler JR (1976) Fractionation by molecular weight of organic substances in Georgia coastal water. Limnol Oceanogr 21:846-852

Wildschutte H, Wolfe DM, Tamewitz A, Lawrence JG (2004) Protozoan predation, diversifying selection, and the evolution of antigenic diversity in Salmonella. Proc Natl Acad Sci USA 101:10644-10649

Wilks SA, Sleigh MA (2004) Lectin binding sites on Euplotes mutabilis (Tuffrau, 1960) and the implications for food particle selection. Eur J Protistol 40:153-162

Submitted: March 23, 2009; Accepted: June 11, 2009

Proofs received from author(s): September 8, 2009 